\title{
STRATEGI BERSAING INDUSTRI MADU (STUDI KASUS: CV MADU APIARI MUTIARA)
}

\author{
COMPETITION STRATEGY OF HONEY INDUSTRY (CASE STUDY: CV MADU APIARI MUTIARA)
}

\author{
Debi Sarah $^{* 1}$, Rita Nurmalina Suryana ${ }^{* *}$, dan Kirbrandoko***) \\ *) Sekolah Bisnis, Institut Pertanian Bogor \\ Jl. Raya Pajajaran, Bogor 16151 \\ ${ }^{* *}$ Departemen Agribisnis, Fakultas Ekonomi dan Manajemen, Institut Pertanian Bogor \\ Jl. Kamper Kampus IPB Darmaga, Bogor 16680 \\ ${ }^{* * *)}$ Pascasarjana Universitas Ibn Khaldun \\ Jl. K.H. Sholeh Iskandar Km. 2 Bogor 16162
}

\begin{abstract}
The amount of imported honey in Indonesia has been increasing since 2013. Import of honey has increased because due to high honey demands on industries of beverage, health, and beauty. The objectives of this research were to determine the internal and external environment factors of CV Madu Apiari Mutiara, to formulate alternative strategies and priorities in developing the company competitive strategy, and to map the recommendation of program and alternative strategy in developing competing strategy CV Madu Apiari Mutiara. The analytical tools used in this research were the internal and external corporate environment analysis, A'WOT integration between hierarchy process analysis (AHP) and SWOT, and the strategy architecture to determine the company's long-term plan. These six alternative strategies are used to determine strategic priorities. The three highest priority strategies are (1) expansion of the marketing area, (2) optimizing market penetration for all honey derivative products, (3) improving product quality and corporate credibility. The designs of the strategic architecture are to improve marketing in the first year, to make a mapping of marketing distribution channels the second year, and to innovate honey derivative products in the third year.
\end{abstract}

Keywords: architecture strategy, A'WOT, CV Madu Apiari Mutiara, honey, competitive strategy

\begin{abstract}
Abstrak: Impor madu di Indonesia mengalami peningkatan pada tahun 2013 hingga saat ini. Impor meningkat karena banyaknya permintaan madu pada industri minuman, kesehatan dan kecantikan. Tujuan dari penelitian ini yaitu menentukan faktor lingkungan internal dan eksternal CV Madu Apiari Mutiara, merumuskan alternatif strategi serta prioritasnya dalam pengembangan strategi bersaing perusahaan, dan memetakan blue print strategi dalam pengembangan strategi bersaing CV Madu Apiari Mutiara. Alat analisis yang digunakan dalam penelitian ini adalah analisis lingkungan internal dan eksternal perusahaan, A'WOT integrasi antara analisis proses hierarki (AHP) dan SWOT, arsitektur strategi untuk menentukan rencana jangka panjang perusahaan. Terdapat enam alternatif strategi yang dapat direkomendasikan kepada CV Madu Apiari Mutiara. Enam alternatif strategi tersebut digunakan untuk menentukan prioritas strategi. Tiga prioritas strategi tertinggi, yaitu (1) perluasan wilayah pemasaran, (2) optimalisasi penetrasi pasar untuk semua produk turunan madu, (3) peningkatan kualitas produk dan kredibilitas perusahaan. Rancangan arsitektur strategi di tahun pertama yaitu melakukan peningkatan pemasaran, tahun kedua membuat pemetaan saluran distribusi pemasaran dan pada tahun ketiga membuat inovasi produk turunan madu.
\end{abstract}

Kata kunci: arsitektur strategi, A’WOT, CV Madu Apiari Mutiara, madu, strategi bersaing

\footnotetext{
${ }^{1}$ Corresponding author:

Email: debisarah24@gmail.com
} 


\section{PENDAHULUAN}

Madu merupakan salah satu produk perlebahan dan termasuk kedalam produk hasil hutan bukan kayu. Potensi pengembangan madu di Indonesia cukup besar, didukung dengan faktor iklim yang tropis dan sumber daya hutan yang dapat dijadikan sebagai ekosistem peternakan lebah madu. Lebah madu merupakan salah satu sumber daya hutan yang potensial untuk dikembangkan dalam pembudidayaannya. Hal ini disebabkan karena sumber pakan lebah yang melimpah (hampir semua tumbuhan yang menghasilkan bunga dapat dijadikan sebagai sumber pakan) baik yang berasal dari tanaman hutan, tanaman pertanian maupun tanaman perkebunan (Setiawan, 2016). Produksi madu petani di Indonesia baru mencapai 5.000 ton per tahun, sedangkan kebutuhan madu yang dibutuhkan mencapai 7.500 ton pertahun dengan asumsi konsumsi perkapita sebesar 30 gr/tahun (Kementrian kehutanan, 2014). Tingkat konsumsi madu perkapita di Indonesia masih cukup rendah, yaitu sekitar 10-15 gr/orang/tahun, dibandingkan dengan konsumsi madu di negara maju seperti Jepang dan Australia yang mencapai 1.2001.500 gr/orang/tahun (Dirjen BPDASPS, 2013). Hal tersebut mengindikasikan bahwa produsen madu dan pebisnis yang bergerak di industry madu memiliki peranan yang penting untuk mengembangkan dan meningkatkan produksi madu agar dapat memenuhi kebutuhan konsumsi dalam negeri. Faktor lain yang menjadi indikasi bahwa peluang pasar untuk usaha madu masih sangat besar ditunjukkan dari tingginya nilai impor madu Indonesia jika dibandingkan dengan nilai ekspornya.

Berdasarkan data Kementerian Perindustrian (2016) nilai impor tertinggi selama lima tahun terakhir adalah tahun 2015 sebesar US\$7.402, hal tersebut berkebalikan dengan nilai ekspor yang sangat kecil di tahun yang sama yaitu sebesar US\$756. Besarnya selisih nilai ekspor dan impor tersebut menandakan permintaan madu untuk konsumsi dalam negeri terus meningkat. Hal tersebut menggambarkan bahwa industri madu memiliki pangsa pasar yang luas dan sangat prospektif sehingga banyak para peternak dan pengusaha madu berkompetisi dibidang usaha madu (Suherman, 2017). Tabel 1 menunjukkan bahwa pangsa pasar madu Indonesia ditempati oleh perusahaan-perusahaan berskala besar yang sudah terlebih dahulu menjual dan memasarkan produknya dalam skala besar. Empat pangsa pasar tertinggi ditempati oleh Madurasa, Madu TJ, Nusantara, dan Tresnojoyo.
Tabel 1. Pangsa pasar madu Indonesia

\begin{tabular}{lc}
\hline Merek & Pangsa Pasar (\%) \\
\hline Madurasa & 56,3 \\
Madu TJ & 27,4 \\
Nusantara & 6,7 \\
Tresnojoyo & 2,2 \\
Lain-lain & 7,4 \\
\hline
\end{tabular}

Sumber: Top Brand Award (2016)

Pangsa pasar yang tersisa dengan jumlah 7,4\% tersebut mewakili para produsen madu yang belum memiliki pangsa pasar yang kuat di Indonesia. Pangsa pasar yang cukup kecil tersebut ditempati oleh produsen-produsen madu berskala kecil dan menengah yang sedang mengembangkan usahahnya diseluruh Indonesia. Hal ini mengindikasikan bahwa banyak produsen madu yang berskala kecil dan menengah berkembang dengan cepat namun belum memiliki daya saing yang baik. Produsen madu berskala kecil dan menengah tersebut memiliki skala produksi dan jumlah penjualan yang masih rendah, serta pemasaran yang dilakukan belum meluas. Banyaknya produsen madu yang tumbuh pada saat ini mengakibatkan tingkat persaingan antar kompetitor semakin meningkat. Tingkat persaingan tersebut dapat dilihat dari sejauh mana produsen tersebut memproduksi berbagai produk turunan, pangsa pasar, pemasaran produk dan peningkatan jumlah penjualannya. Beberapa produsen madu skala kecil dan menengah dan memiliki merek dagang sendiri, yaitu PT Madu Pramuka dengan nama dagang Madu Pramuka, Perum Perhutani dengan nama dagang Madu Perhutani, dan PT Suba Alam Muda dengan nama dagang Madu Alam Sumbawa.

Melihat kondisi pasar tersebut salah satu pelaku bisnis yang optimis terhadap persaingan industri perlebahan saat ini adalah CV. Madu Apiari Mutiara. Keunggulan perusahaan ini adalah tidak hanya menjual madu murni (madu botol), namun juga menjual madu formula yang terkandung didalamnya adalah madu murni yang dicampur dengan bahan-bahan herbal. Pada awal proses produksi CV. Madu Apiari Mutiara melakukan ternak lebah madu sendiri untuk mencukupi kebutuhan produksinya, namun jumlah produksi madu yang dihasilkan tidak dapat memenuhi kebutuhan produksi maka perusahaan melakukan kemitraan dengan beberapa pemasok. Pemasok madu tersebut berasal dari mitra peternak lebah madu di Subang dan Pati atau mengambil madu hutan di Sumatera (Riau, Jambi, Palembang dan Padang), dalam sehari perusahaan dapat menghasilkan 1000-1500 botol madu dengan beberapa 
varian ukuran untuk memenuhi permintaan konsumen. Banyaknya permintaan dan kebutuhan konsumen akan produk baru berbahan dasar madu maka perusahaan memunculkan inovasi baru untuk beberapa jenis produk turunan madu dalam bidang kecantikan dan kesehatan seperti, masker madu, sabun madu, cream madu dan propolis.

CV Madu Apiari Mutiara selaku perusahaan menyadari bahwa ada beberapa hal yang harus diperbaiki didalam manajemen perusahaannya seperti sistem pemasaran yang belum optimal yang sebagian besar pemasaran produk madunya menggunakan sistem maklon dengan pihak Serambi Botani dan hanya terfokus di daerah Jabodetabek. Permasalahan eksternal yang dialami perusahaan yaitu banyaknya kompetitor sejenis yang memproduksi madu dengan bentuk botol dan jenis madu yang serupa. Hal tersebut yang mendasari perusahaan agar mempunyai strategi bersaing yang tepat untuk pengembangan perusahaan kedepannya. Kelangsungan hidup dan keberhasilan perusahaan, bergantung pada kemampuan perusahaan untuk memantau dan beradaptasi terhadap lingkungan internal dan eksternal bisnisnya (Tan dan Tan, 2005).

Terdapat beberapa penelitian yang menyinggung beberapa hal yang dibahas dalam penelitian ini antara lain Penelitian Kamila (2017) yang berjudul analisis pengembangan bisnis madu pada CV AthThoifah dengan pendekatan Business Model Canvas menghasilkan strategi bisnis baru yaitu dengan mengembangkan bisnis di kota-kota besar diluar Jabodetabek, menambah distributor dan agen secara lebih intens dan menjalin kemitraan khusus. Selain itu penelitian dari O'Regan et al. (2008) yang berjudul The Strategic Planning Environment Performance Relationship Revisited in Manufacturing SME menyebutkan bahwa analisis lingkungan internal dan eksternal perusahaan dapat memberikan panduan penerapan strategi bisnis untuk mencapai tujuan perusahaan secara efektif. Perbedaan penelitian terdahulu dengan penelitian yang dilakukan di CV Madu Apiari Mutiara, yaitu terletak pada strategi bisnis yang akan dilakukan perusahaan kedepannya. CV Madu Apiari Mutiara melakukan strategi bisnis fokus terhadap produk dan pasar, yaitu dengan memperkenalkan dan mengembangkan produk-produk turunan madu kepada konsumen dan pasar yang lebih luas.
Penelitian ini bertujuan 1) mengetahui faktor-faktor internal dan eksternal yang berpengaruh dalam pengembangan startegi besaing CV Madu Apiari Mutiara; 2) merumuskan alternatif strategi yang tepat dan prioritas strategi untuk dilakukan dalam pengembangan strategi bersaing CV Madu Apiari Mutiara; 3) memetakan blue print strategi dalam pengembangan strategi bersaing CV Madu Apiari Mutiara. Ruang lingkup penelitian ini difokuskan pada penjualan perusahaan yang fluktuatif, kelangkaan perusahaan dalam memperoleh bahan baku, kenaikan harga bahan baku, pemasaran CV Madu Apiari Mutiara yang belum meluas, dan persaingan dalam industri madu.

\section{METODE PENELITIAN}

Penelitian ini dilakukan di CV. Madu Apiari Mutiara, Cimanggis-Depok. Pemilihan lokasi dipilih secara sengaja atau purposive dengan pertimbangan bahwa perusahaan tersebut merupakan perusahaan pengolahan madu dengan kualitas produk madu berskala internasional. Penelitian dilaksanakan pada bulan September-Desember 2017 untuk pengambilan data dan penulisan. Pemilihan sampel dilakukan secara purposive sampling, yaitu informan (key person) yang memiliki keahlian, pengalaman dan informasi lebih pada data yang ingin diketahui. Sampel (internal dan eksternal) adalah mereka yang terlibat langsung maupun tidak langsung serta mempunyai pengaruh dalam bisnis pengolahan madu di CV Madu Apiari Mutiara. Adapun pihak internal yaitu pemilik perusahaan, manager produksi, dan manager pemasaran, sedangkan pihak eksternal yaitu petani madu sebagai pemasok, pembeli, Dinas Perindustrian dan Perdagangan Depok dan Dinas Kehutanan Bogor.

Data yang digunakan terdiri dari dua jenis data yaitu data primer dan data sekunder. Data primer merupakan data yang didapatkan melalui hasil wawancara (indepth interview). Hasil yang didapatkan dari data primer ini digunakan oleh peneliti untuk menjawab tujuan penelitian yang telah dirumuskan untuk identifikasi faktor internal dan eksternal, menentukan alternatif strategi dan memetakan rekomendasi program rutin dan pertahunnya. 
Pengumpulan data dilakukan melalui beberapa tahap yang diawali dengan wawancara dengan para responden. Dari hasil wawancara akan diperoleh informasi terkait dengan faktor-faktor internal (kekuatan dan kelemahan) dan eksternal (peluang dan ancaman) yang memengaruhi strategi bersaing perusahaan. Pada tahap kedua, hasil pada tahap pertama digunakan utuk menyusun kuisioner tahap kedua. Wawancara tahap kedua dilakukan penilaian terhadap faktorfaktor SWOT (Strength, Weaknesses, Opportunities, dan Threats) dengan perbandingan berpasangan untuk mengetahui faktor yang paling berpengaruh. Pengolahan dan analisis data pada penelitian ini dilakukan secara kualitatif dan kuantitatif. Data kulitatif disajikan dalam bentuk deskriptif untuk mendeskripsikan gambaran umum dan faktor-faktor internal dan eksternal CV Madu Apiari Mutiara. Data kuantitatif berupa pembobotan untuk faktor-faktor internal dan eksternal kemudian pembobotan untuk tahap pengambilan keputusan dan penentuan prioritas strategi.

Metode penelitian yang digunakan yaitu metode A'WOT kombinasi dari AHP (Analytical Hierarchy Process) dengan analisis SWOT. A'WOT bertujuan menganalisis faktor internal eksternal perusahaan dan memberikan rekomendasi dari strategi alternatif untuk perusahaan (Wulandari, 2017). Penggunaan analisis A'WOT pada perusahaan besar maupun perusahaan kecil dan menengah tidak jauh berbeda proses maupun langkahnya. Keduanya diawali dengan melakukan identifikasi lingkungan bisnis, menganalisis SWOT lalu menentukan prioritas strategi. Hal ini didukung oleh pernyataan Oreski (2012) bahwa setiap organisasi memiliki kondisi lingkungan internal dan eksternal yang bervariatif dan unik yang pada satu sisi akan menstimulus tercapainya tujuan sedangkan di sisi yang lain akan menjadi potensi ancaman organisasi. Menurut Osuna (2007) struktur hirarki dibagi dalam empat tingkatan. Tingkat pertama adalah tujuan (goal) yang ingin dicapai oleh keputusan; tingkat kedua didasari oleh empat kelompok faktor seperti yang didefinisikan oleh teknik SWOT: Kekuatan (S), Kelemahan (W), Opportunities (O) dan Ancaman (T); tingkat ketiga didasari oleh faktor-faktoryang termasuk dalam masingmasing dari empat kelompok tingkat sebelumnya; dan akhirnya, tingkat keempat didasari oleh strategi yang harus dievaluasi dan dibandingkan.
Setelah menentukan faktor internal dan eksternal perusahaan, tahap selanjutnya yaitu menentukan alternative strategi perusahaan melalui indepth interview dalam menentukan alternatif strategi dibutuhkan alat analisis SWOT. Menurut David (2009) analisis SWOT membantu untuk mengembangkan empat jenis strategi, yaitu strategi SO (StrengthsOpportunities), WO (Weakness-Opportunities), ST (Strengths-Threats), dan WT (Weakness-Threats). SWOT memungkinkan penggunanya untuk menentukan alternatif strategi berdasarkan kombinasi faktor internal dan eksternalnya. Namun, kelemahan dari pendekatan analisis SWOT ini adalah tidak mampu mengevaluasi secara komprehensif keputusan strategi dan hanya mampu mengidentifikasi faktor penyebab (Ghorbanian et al. 2015). Oleh karena itu dibutuhkan pendekatan lain yang mampu melengkapi kelemahan analisis SWOT dalam mengevauasi keputusan strategi secara komprehensif. Salah satu pendekatan yang dapat digunakan untuk melengkapi SWOT ialah AHP. AHP digunakan dalam SWOT untuk memberikan rating dan rangking pada faktor strategisnya (Zarei dan Paghaleh, 2011).

Analisis AHP digunakan untuk menentukan prioritas strategi yang akan digunakan oleh perusahaan. AHP adalah teori dari perhitungan perbandingan berpasangan dan penilaian dari ahli untuk mendapatkan skala prioritas. Perbandingan yang dibuat dengan menggunakan skala dari penilaian yang memperlihatkan tingkat kepentingannya, dominasi dari satu elemen terhadap elemen yang lain. Penelitian yang diberikan dapat bersifat tidak konsisten dan bagaimana cara untuk mengukur nilai konsistensinya dapat dilakukan dengan AHP (Saaty, 2008). Prioritas dibuat pada setiap objek disetiap level, setiap level berhubungan dengan level diatas dan dibawahnya dan seluruh sistem terhubung satu sama lain sehingga dapat memecahkan suatu masalah (Banuelas dan Antony, 2004). Proses AHP digunakan untuk membantu dalam membangun model dan membantu mengambil keputusan serta menghasilkan kesimpulan yang dimbil menurut evaluasi berdasarkan pengetahuan dan penilaian (Dalalah et al. 2010). Prinsip kerja AHP adalah penyerderhanaan suatu persoalan kompleks yang tidak terstruktur, strategik, dan dinamik menjadi bagian-bagiannya, serta menata dalam suatu hierarki (Triantaphyllou dan Mann, 1995). 
Setelah menentukan prioritas strategik untuk perusahaan maka akan disusun rekomendasi program kegiatan perusahaan jangka panjang dan jangka menengah dengan menggunakan arsitektur strategik. Perumusan arsitektur strategik dilakukan dengan mempertimbangkan input-input berupa hasil identifikasi terhadap visi, misi dan tujuan, tantangan yang dihadapi dan sasaran yang ingin dicapai oleh CV Madu Apiari Mutiara. Pada penelitian ini, arsitektur strategik diturunkan dari hasil matriks SWOT berupa strategi SO, WO, ST dan WT. Arsitektur strategi merupakan peringkasan strategi yang dibuat dalam bentuk peta, sehingga memudahkan pembaca untuk memahami strategi tersebut. Penyusunan arsitektur strategik merupakan lanjutan dari proses analisis lingkungan internal, lingkungan eksternal dan strategi SWOT yang telah dilakukan pada tahap sebelumnya. Adapun proses pembuatan arsitektur strategis menurut Yoshida (2006) yang pertama menentukan sasaran dan tantangan, melakukan analisis SWOT, menentukan program kerja dan jangka waktu pelaksanaan, selanjutnya menyusun aristektur strategik. Susunannya dapat dilihat pada Gambar 1.

Langkah awal yang harus dilakukan peneliti adalah dengan melihat masalah umum yang ada diperusahaan dan melihat visi misi dari perusahaan. Dalam penelitian ini tahapan pertama yang dilakukan oleh peneliti adalah menentukan faktor internal dan eksternal perusahaan menggunakan cara depth interview. Tahapan kedua adalah menentukan alternative strategi bersaing dengan menggunakan matriks SWOT. Tahapan ketiga adalah menentukan rekomendasi prioritas strategi perusahaan. Tahapan keempat adalah menentukan blue print strategi perusahaan dengan menggunakan arsitektur strategik. Kerangka pemikiran dapat dilihat pada Gambar 2.

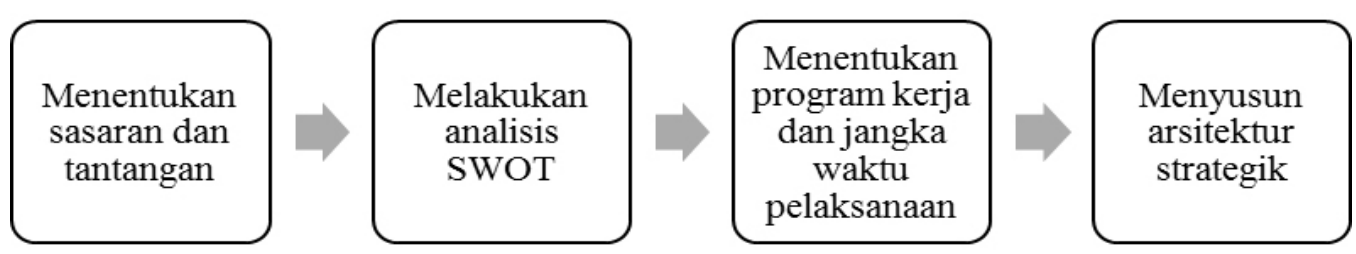

Gambar 2. Tahapan pembuatan arsitektur strategi

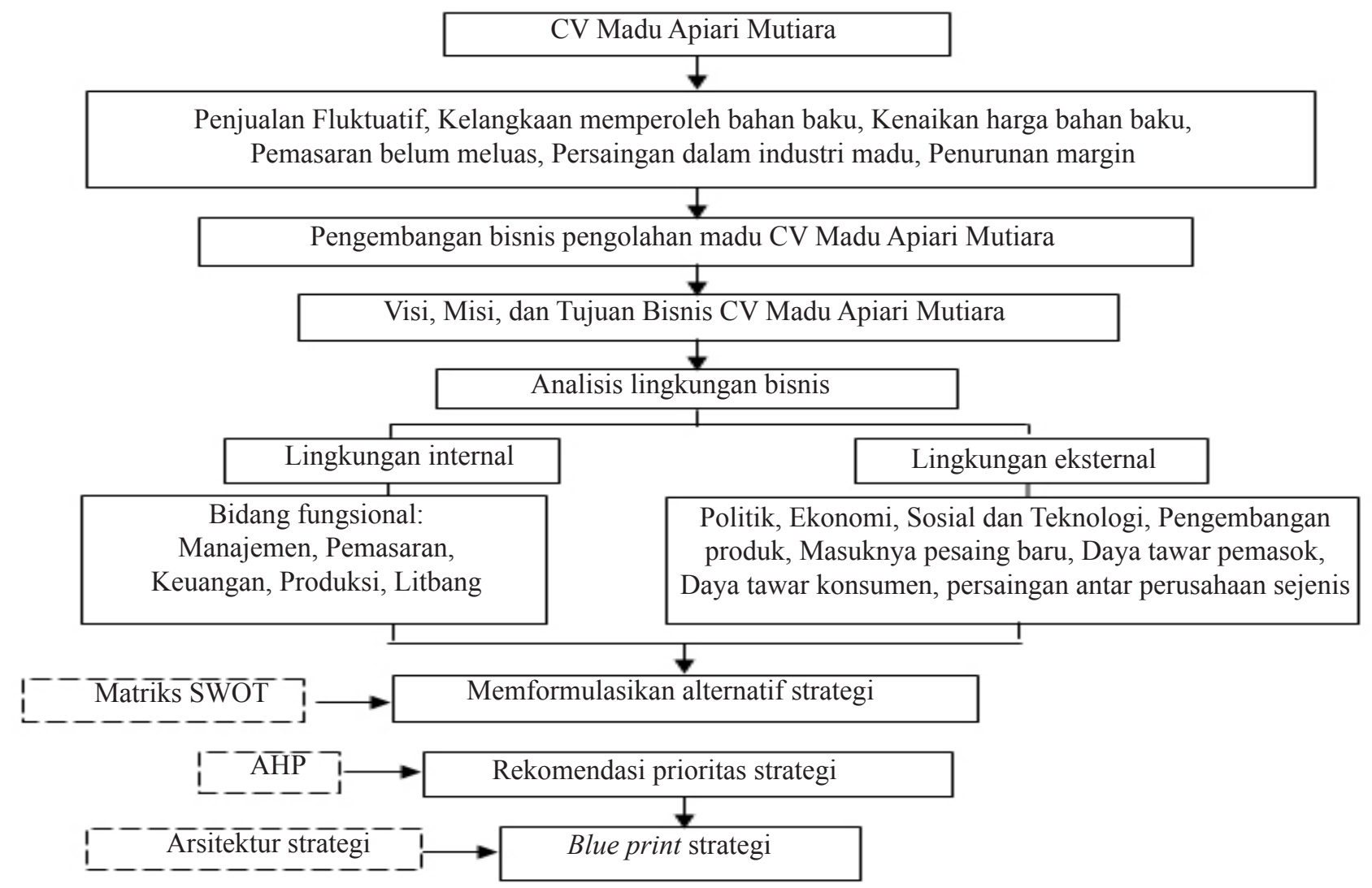

Gambar 1. Kerangka pemikiran penelitian 
HASIL

\section{Analisis Lingkungan Internal dan Eksternal Perusahaan}

Keberhasilan usaha suatu perusahaan akan bergantung pada lingkungan internal dan eksternalnya. Analisis lingkungan internal CV Madu Apiari Mutiara terdiri dari kekuatan dan kelemahan, sedangkan analisis lingkungan eksternal terdiri dari peluang dan ancaman. Analisis lingkungan internal dan eksternal perusahaan beserta alternatif strateginya pada Tabel 2 .

Analisis lingkungan internal CV Madu Apiari Mutiara dilakukan dengan mengidentifikasi kekuatan dan kelemahan yang dimiliki oleh perusahaan dengan cara indepth interview. Kekuatan yang dimaksud ialah segala hal yang menjadi faktor kunci untuk mencapai tujuan dan hanya dimiliki CV Madu Apiari Mutiara. Sedangkan kelemahan ialah segala hal yang dapat menggagalkan tercapainya tujuan yang berasal dari dalam CV Madu Apiari Mutiara. Analisis lingkungan eksternal bertujuan untuk mengidentifikasi sejumlah peluang dan ancaman yang berada di lingkungan eksternal perusahaan. Peluang merupakan tren positif yang berada di lingkungan eksternal perusahaan yang berpotensi memberikan laba pada perusahaan. Sedangkan ancaman merupakan tren negatif pada lingkungan eksternal perusahaan yang berpotensi menimbulkan kerugian pada perusahaan (Solihin, 2012).

Analisis lingkungan internal perusahaan terdiri dari faktor kekuatan dan faktor kelemahan. Terdapat faktor kekuatan perusahaan yang terdiri dari kualitas produk madu berstandar SNI dan internasional, karyawan yang kompeten, produk yang beragam, sanitasi dan SOP pada divisi produksi, penelitian dan pengembangan produk madu. Faktor kelemahan perusahaan terdiri dari keterbatasan bahan baku madu ternak sendiri, kurangnya fasilitas produksi, pemasaran produk hanya di Jabodetabek, kemasan produk mudah ditiru.

Tabel 2. Matriks SWOT CV Madu Apiari Mutiara

\begin{tabular}{|c|c|c|}
\hline Eksternal & $\begin{array}{l}\text { Kekuatan (Strengths) } \\
\text { 1. Kualitas produk madu berstandar } \\
\text { SNI dan internasional } \\
\text { 2. Karyawan yang kompeten } \\
\text { 3. Produk yang beragam } \\
\text { 4. Sanitasi dan SOP pada divisi } \\
\text { produksi } \\
\text { 5. Penelitian dan pengembangan } \\
\text { produk madu }\end{array}$ & $\begin{array}{l}\text { Kelemahan (Weaknesess) } \\
\text { 1. Keterbatasan bahan baku madu } \\
\text { ternak sendiri } \\
\text { 2. Kurangnya fasilitas produksi } \\
\text { 3. Pemasaran produk hanya di } \\
\text { Jabodetabek } \\
\text { 4. Kemasan produk mudah ditiru }\end{array}$ \\
\hline $\begin{array}{l}\text { Peluang (Opportunities) } \\
\text { 1. Pelanggan loyal } \\
\text { 2. Lokasi pemasaran yang masih luas } \\
\text { 3. Permintaan madu meningkat karena } \\
\text { pola hidup sehat yang meningkat } \\
\text { 4. Teknologi informasi yang } \\
\text { dimanfaatkan untuk pemasaran } \\
\text { madu online } \\
\text { 5. Membuat produk turunan madu } \\
\text { dibidang kesehatan dan kecantikan }\end{array}$ & $\begin{array}{l}\text { Strategi SO } \\
\text { 1. Perluasan wilayah pemasaran.(S1, } \\
\mathrm{S} 2, \mathrm{~S} 3, \mathrm{~S} 4, \mathrm{O} 1, \mathrm{O} 2, \mathrm{O} 3, \mathrm{O} 4) \\
\text { 2. Peningkatan inovasi produk dalam } \\
\text { bidang kecantikan dan kesehatan } \\
(\mathrm{S} 5, \mathrm{O} 5)\end{array}$ & $\begin{array}{l}\text { Strategi WO } \\
\text { 1. Optimalisasi penetrasi pasar untuk } \\
\text { semua produk turunan madu (W3, } \\
\text { O2) }\end{array}$ \\
\hline $\begin{array}{l}\text { Ancaman (Threaths) } \\
\text { 1. Kenaikan harga bahan baku madu } \\
\text { 2. Kelangkaan bahan baku madu di } \\
\text { petani/ supplier } \\
\text { 3. Tingkat persaingan yang tinggi } \\
\text { antar perusahaan sejenis } \\
\text { 4. Pesaing semakin baik dalam } \\
\text { menciptakan brand image produk }\end{array}$ & $\begin{array}{l}\text { Strategi ST } \\
\text { 1. Peningkatan mutu dan kualitas } \\
\text { keaslian produk madu serta } \\
\text { peningkatan kredibilitas perusahaan } \\
\text { agar konsumen loyal (S1, S2, S3, } \\
\text { S4, S5, T3, T4) }\end{array}$ & $\begin{array}{l}\text { Strategi WT } \\
\text { 1. Pengenalan brand image } \\
\text { (karakteristik \& keunikan) produk } \\
\text { madu kepada konsumen dan } \\
\text { melakukan pemasaran aktif di } \\
\text { berbagai wilayah melalui pameran, } \\
\text { media cetak dan media sosial (W3, } \\
\text { W4,T3,T4) } \\
\text { 2. Penambahan jumlah koloni } \\
\text { lebah untuk beternak sendiri dan } \\
\text { peningkatan modal perusahaan } \\
\text { (W1,W2,T1,T2) }\end{array}$ \\
\hline
\end{tabular}


Analisis lingkungan eksternal perusahaan terdiri dari faktor peluang dan faktor ancaman. Faktor peluang perusahaan terdiri dari pelanggan loyal, lokasi pemasaran yang masih luas, permintaan madu yang meningkat karena pola hidup sehat, teknologi informasi yang dimanfaatkan untuk pemasaran madu online, membuat produk turunan madu dibidang kesehatan dan kecantikan. Faktor ancaman perusahaan terdiri dari kenaikan harga bahan baku, kelangkaan bahan baku dipetani / supplier, persaingan yang tinggi antar perusahaan sejenis, pesaing semakin baik dalam menciptakan brand image produk

\section{Alternatif Strategi Perusahaan dan Prioritas Strategi Perusahaan}

Alternatif strategi disusun berdasarkan faktor-faktor internal (kekuatan dan kelemahan) serta eksternal (peluang dan ancaman). Penelitian yang dilakukan oleh Dugo (2011) dan David et al. (2016) pada arsitektur strategis menggunakan metode analisis deskriptif untuk lingkungan bisnis (internal dan eksternal), analisis tinjauan industri masa depan dan desain arsitektur strategis yang kemudian dilanjutkan dengan penetapan prioritas melalui AHP. Matriks SWOT menghasilkan alternatif strategi yang dikelompokkan menjadi empat strategi umum, yaitu SO, WO, ST dan WT.

Strategi SO (Strength-Opportunity) Strategi ini bertujuan menggunakan kekuatan yang dimiliki untuk memanfaatkan peluang. Adapun strategi SO yang telah dirumuskan, yaitu 1) Perluasan wilayah pemasaran; 2) Peningkatan inovasi produk dalam bidang kesehatan dan kecantikan. Strategi WO (Weaknesses-Opportunity) bertujuan meminimalkan atau memperbaiki kelemahan dengan cara mengambil manfaat dari peluang. Adapun strategi WO yang telah dirumuskan adalah optimalisasi penetrasi pasar untuk semua produk turunan madu. Pemasaran produk yang dilakukan oleh perusahaan yaitu pada wilayah jabodetabek dan sebagian besar terfokus di Depok dan Bogor. Wilayah pemasaran yang belum terlalu luas dan harus diperbaiki dengan strategi pemasaran yang baik. Strategi ST (StrengthThreat) diciptakan dengan menggunakan kekuatan CV Madu Apiari Mutiara untuk menghindari atau mengatasi ancaman. Adapun strategi ST yang telah dirumuskan adalah peningkatan kualitas produk dan kredibilitas perusahaan. Ancaman terbesar perusahaan terdiri dari persaingan antar perusahaan sejenis dan Pesaing semakin baik dalam menciptakan brand image produk. Strategi WT (Weaknesses-Threat) diciptakan untuk meminimalkan kelemahan dan menghindari ancaman yang dimiliki oleh perusahaan. Strategi WT, yaitu 1) Pengenalan brand image produk madu kepada konsumen dan melakukan pemasaran aktif di berbagai wilayah; 2) Penambahan jumlah koloni lebah untuk beternak sendiri dan peningkatan modal perusahaan.

Dalam menentukan prioritas strategi perusahaan diperlukan analisis A'WOT (AHP dan SWOT). Pada analisis A'WOT peneliti harus menentukan struktur hierarki yang terdiri dari level pertama adalah goal atau tujuan, yaitu keputusan yang dijalankan dalam mengembangkan strategi bersaing usaha madu CV Madu Apiari Mutiara. Level kedua adalah kekuatan, kelemahan, peluang dan ancaman pada faktor SWOT, masing-masing faktor tersebut memiliki nilai. Faktor kekuatan dengan nilai 0,394 , faktor kelemahan dengan nilai 0,104 , faktor peluang dengan nilai 0,320 , dan faktor ancaman dengan nilai 0,181. Level ketiga adalah subfaktor yaitu hasil dari analisis lingkungan internal dan eksternal perusahaan yang merupakan faktor kekuatan yang terdiri dari lima subfaktor, faktor kelemahan terdiri dari empat subfaktor, faktor peluang terdiri dari lima subfaktor dan faktor ancaman terdiri dari empat subfaktor. Level keempat merupakan alternatif strategi yang didapat dari matriks SWOT. Terdapat dua alternatif strategi SO, satu alternatif strategi WO, satu alternatif strategi ST dan dua alternatif strategi WT. Struktur hierarki pada penelitian ini secara utuh digambarkan seperti Gambar 3.

Pengolahan analisis proses hierarki yaitu menganalisis pendapat gabungan para responden menunjukkan pembobotan pada level faktor menghasilkan bobot tertinggi pada faktor kekuatan dengan nilai 0,394 kemudian diikuti oleh peluang, ancaman, dan kelemahan dengan masing-masing nilai 0,320 , 0,$181 ; 0,104$ dengan nilai inconsistency 0,03 . Hal ini menunjukkan bahwa penilaian tersebut memenuhi syarat perbandingan berpasangan. Faktor kekuatan perusahaan yang memiliki bobot tertinggi 0,318, yaitu kualitas produk, CV Madu Apiari Mutiara memiliki kualitas produk yang berstandar SNI dan internasional, kedua kualitas produk tersebut dapat dibedakan melalui kadar air yang terkandung didalam madu. Madu kualitas SNI memiliki kadar air 18\% sedangkan madu kualitas internasional memiliki kadar air $10-15 \%$. Semakin kecil kadar air yang terkandung dalam madu maka madu akan semakin kental. Nilai inconsistency pada faktor kelemahan adalah 0,01. Kelemahan perusahaan adalah pemasaran produk pasif dengan nilai 
sebesar 0,359 . Pemasaran produk yang dilakukan oleh perusahaan masih bersifat pasif karena sebagian besar pemasaran hanya dilakukan di wilayah Depok dan Bogor. Pemasaran yang dilakukan di wilayah Jakarta, Bekasi dan Tangerang belum maksimal, contohnya pemasaran pada diwilayah Jakarta hanya pada koperasi perkantoran, agen madu dan toko herbal.

Nilai inconsistency pada faktor peluang, yaitu 0,04. Permintaan madu yang meningkat karena pola hidup sehat menurut para responden merupakan faktor peluang yang paling tinggi, yaitu bernilai 0,279 . Masyarakat pada umumnya jarang sekali mengkonsumsi madu untuk kebutuhan sehari-hari, namun seiring berjalannya waktu saat ini banyak masyarakat mengkonsumsi madu sebagai pengganti dari gula. Pola hidup sehat yang meningkat pada saat ini dapat mendorong meningkatkan permintaan madu. Nilai inconsistency pada faktor ancaman yang paling penting dan harus dihindari yaitu kelangkaan bahan baku dengan nilai 0,616. Menurut hasil wawancara yang dilakukan dengan petani madu, produksi madu mengalami penurunan mulai tahun 2010 sampai dengan saat ini hal ini disebabkan oleh iklim yang tidak menentu dan lahan perkebunan yang semakin berkurang. Penurunan tersebut khususnya pada jenis madu ternak. Pembobotan faktor SWOT dapat dilihat pada Tabel 3 .
Hasil dari prioritas strategi ditunjukkan oleh nilai evaluasi keseluruhan dari setiap strategi dalam mengambil keuntungan faktor kekuatan, mengurangi efek dari faktor kelemahan, memanfaatkan faktor peluang dan menghadapi faktor ancaman (Darmawan et al. 2015). Prioritas strategi dilakukan pada enam alternatif strategi yang telah didapatkan dari kombnasi SWOT. Pada tahap ini diberikan nilai pada setiap alternatif strategi untuk menentukan prioritas utama yang harus didahulukan. Dari hasil perbandingan berpasangan diperoleh overall inconsistency bernilai 0,03 dan prioritas pertama adalah memperluas wilayah pemasaran dengan nilai sebesar 4,306836. Prioritas kedua adalah membuat pemetaan saluran distribusi dan pemasaran dengan nilai sebesar 4,028598. Prioritas ketiga adalah mempertahankan kualitas produk dan kredibilitas perusahaan dengan nilai sebesar 4,01988. Prioritas keempat adalah meningkatkan inovasi produk kecantikan dankesehatan dengan nilai sebesar 3,879486. Prioritas kelima adalah memunculkan karakteristik dan keunikan produk (kemasan baru) dengan nilai sebesar 3,490634. Prioritas keenam adalah menambah jumlah koloni lebah dan peningkatan modal perusahaan dengan nilai sebesar 3,394597. Tabel 4 menunjukkan urutan prioritas strategi CV Madu Apiari Mutiara.

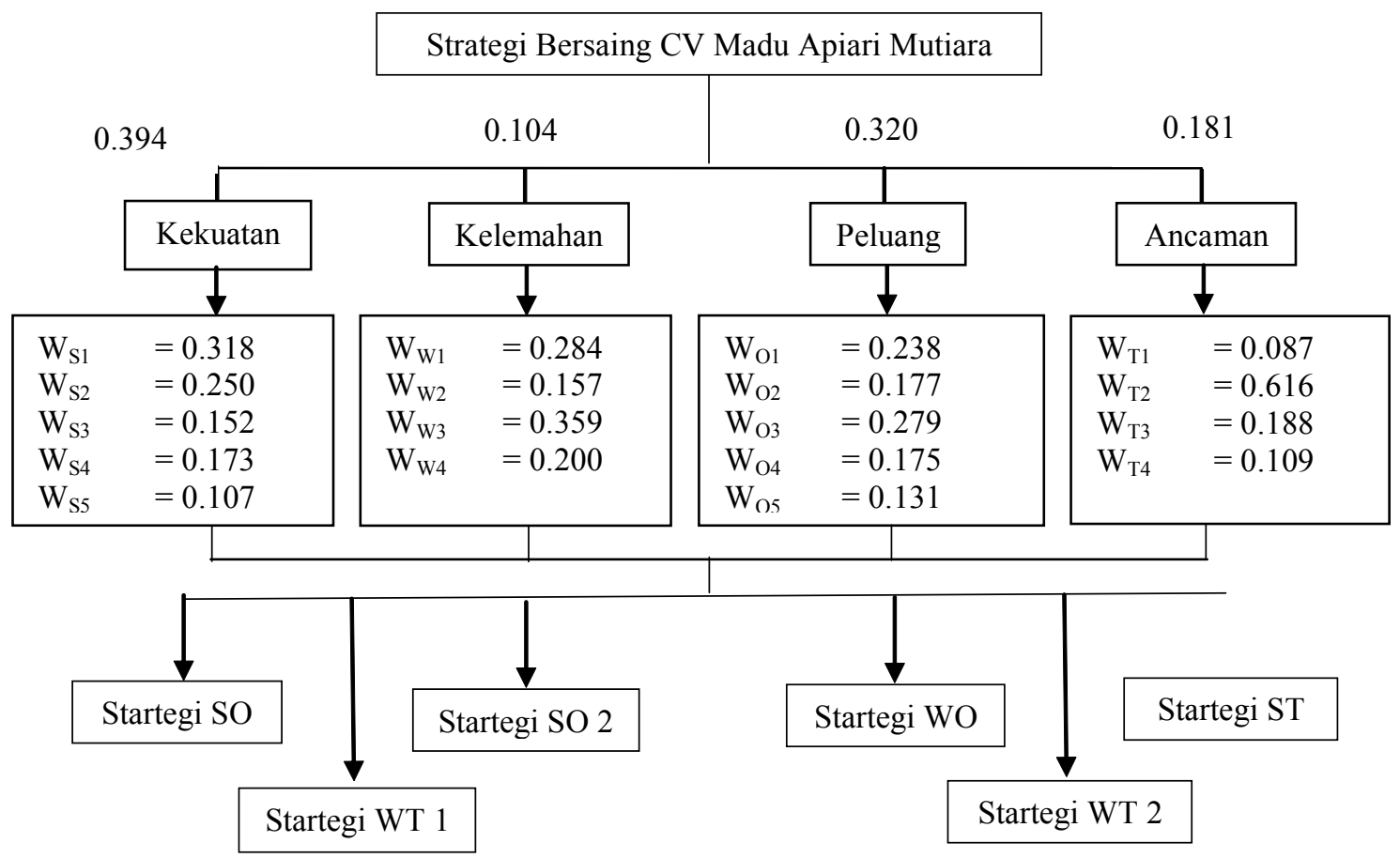

Gambar 3. Struktur hirarki strategi bersaing industri madu CV Madu Apiari Mutiara 
Tabel 3. Bobot prioritas faktor SWOT strategi bersaing CV Madu Apiari Mutia

\begin{tabular}{|c|c|c|c|c|}
\hline Faktor SWOT & Inconsistency & Subfaktor SWOT & Bobot global & Bobot faktor \\
\hline \multirow[t]{6}{*}{ Kekuatan } & 0,03 & & 0,394 & \\
\hline & & Kualitas produk madu berstandar SNI dan internasional & 0,125 & 0,318 \\
\hline & & Karyawan yang kompeten & 0,099 & 0,250 \\
\hline & & Produk yang beragam & 0,059 & 0,152 \\
\hline & & Sanitasi dan SOP pada divisi produksi & 0,068 & 0,173 \\
\hline & & Penelitian dan pengembangan produk madu & 0,042 & 0,107 \\
\hline \multirow[t]{5}{*}{ Kelemahan } & 0,01 & & 0,104 & \\
\hline & & Keterbatasan bahan baku madu ternak sendiri & 0,029 & 0,284 \\
\hline & & Kurangnya fasilitas produksi & 0,016 & 0,157 \\
\hline & & Pemasaran produk hanya Jabodetabek & 0,037 & 0,359 \\
\hline & & Kemasan produk mudah ditiru & 0,020 & 0,200 \\
\hline \multirow[t]{6}{*}{ Peluang } & 0,04 & & 0,320 & \\
\hline & & Pelanggan loyal & 0,076 & 0,238 \\
\hline & & Lokasi pemasaran yang masih luas & 0,056 & 0,177 \\
\hline & & Permintaan madu meningkat karena pola hidup sehat & 0,089 & 0,279 \\
\hline & & Teknologi informasi & 0,056 & 0,175 \\
\hline & & $\begin{array}{l}\text { Membuat produk turunan madu dibidang kesehatan dan } \\
\text { kecantikan }\end{array}$ & 0,041 & 0,131 \\
\hline \multirow[t]{5}{*}{ Ancaman } & 0,03 & & 0,181 & \\
\hline & & Kenaikan harga bahan baku & 0,015 & 0,087 \\
\hline & & Kelangkaan bahan baku dipetani / supplier & 0,111 & 0,616 \\
\hline & & Persaingan tinggi antar perusahaan sejenis & 0,034 & 0,188 \\
\hline & & $\begin{array}{l}\text { Pesaing semakin baik dalam menciptakan brand image } \\
\text { produk }\end{array}$ & 0,019 & 0,109 \\
\hline
\end{tabular}

Tabel 4. Urutan prioritas strategi bersaing CV Madu Apiari Mutiara

\begin{tabular}{llcc}
\hline Tipe strategi & Strategi & Nilai Evaluasi & Prioritas \\
\hline S-O & Perluasan wilayah pemasaran & 4,306836 & 1 \\
S-O & Peningkatan inovasi produk kecantikan dan kesehatan & 3,879486 & 4 \\
W-O & Optimalisasi penetrasi pasar untuk semua produk turunan madu & 4,028598 & 2 \\
S-T & Peningkatan kualitas produk dan kredibilitas perusahaan & 4,01988 & 3 \\
W-T & Pengenalan brand image produk kepada konsumen (karakteristik produk) & 3,490634 & 5 \\
W-T & Penambahan jumlah koloni lebah dan peningkatan modal perusahaan & 3,394597 & 6 \\
\hline
\end{tabular}

Penelitian terdahulu mengenai prioritas strategi dan arsitektur strategi dalam bidang agribisnis dilakukan oleh Oktavia et al. (2017) penelitian tersebut menghasilkan hasil analisis proses integrasi bisnis di PT Sierad Produce pada saat ini dan hasil analisis tinjauan masa depan industri (industry foresight) dijadikan acuan untuk menentukan strategi perusahaan kedepan. Alternatif strategi perusahaan diperoleh berdasarkan tiga tujuan utama, yaitu memaksimalkan integrase perusahaan, pengembangan produk dan pengembangan pasar. Prioritas kepentingan utama pada faktor eksternal adalah konsumen, dan tujuan utama adalah pengembangan produk.

\section{Blue Print Perusahaan Dengan Arsitektur Strategi Dalam Pengembangan Strategi Bersaing CV Madu Apiari Mutiara}

Rancangan arsitektur strategik merupakan rekomendasi yang diberikan sebagai jawaban atas tantangan yang dihadapi perusahaan. Rancangan ini merupakan peta strategi (blue print strategy) untuk mencapai sasaran atau pengembangan bisnis madu. Sasaran yang ingin dicapai oleh CV Madu Apiari Mutiara ialah menjadi perusahaan pengolahan madu yang mandiri dan berkelanjutan. Mandiri dan berkelanjutan yang dimaksud ialah 1) memiliki ketersediaan bahan baku 
madu yang stabil; 2) meningkatkan fasilitas produksi perusahaan; 3) wilayah pemasaran produk perusahaan lebih luas; 4) produk lebih dikenal oleh masyrakat luas; 5) lebih memperkenalkan produk turunan madu kepada konsumen.

Beberapa tantangan yang dihadapi oleh CV Madu Apiari mutiara dalam mengembangkan bisnisnya yaitu 1) kenaikan harga bahan baku dan pasokan madu yang tidak menentu; 2) keterbatasan modal perusahaan; 3) biaya pemasaran dan banyak target pasar yang belum dipetakan; 4) banyak pesaing sejenis memiliki citra produk yang lebih baik; 5) memberi penjelasan lebih kepada konsumen yang belum mengetahui manfaat dan kegunaan dari produk turunan madu dan melakukan pemasaran aktif pada produk ini.

Terdapat dua belas klasifikasi program yang direkomendasikan untuk mencapai sasaran yang diharapkan, yaitu program yang dilaksanakan secara terus menerus dan program yang dilaksanakan secara bertahap. Program yang dilaksanakan secara terus menerus akan dilakukan sepanjang tahun pelaksanaan program. Terdapat 12 Program kerja yang dilakukan secara bertahap diturunkan dari alternatif kebijakan yang telah dibuat, yaitu 1) Melakukan kerjasama dengan rumah sakit, apotek dan distributor baru diwilayah Jabodetabek dan dikota-kota besar lainnya; 2) menjalin kerjasama dengan retail dan convinience store; 3) membuka stand penjualan/outlet sendiri didaerah Jakarta, Bandung, Semarang dan Surabaya; 4) membuat brosur yang berisi gambar produk, manfaat dan harga produk; 5) melakukan promo bundling untuk pembelian produk madu; 6) membuat pemetaan saluran distribusi dan pemasaran nasional (diluar pulau Jawa); 7) pemilihan pasar yang memiliki prioritas penjualan madu tertinggi; 8) mengikuti pameran kegiatan produk herbal alami yang dilakukan disetiap daerah atau skala nasional; 9) membuat kemasan produk yang unik, praktis dan mudah digunakan; 10) membuat inovasi produk kesehatan madu berbentuk sachet, pasta gigi, obat kumur dan minuman ready to drink; 11) membuat inovasi produk kecantikan berbentuk body lotion atau pelembab madu; 12) melakukan kerja sama dengan petani untuk menghasilkan madu ternak sendiri.

Rekomendasi program-program yang harus dilaksanankan secara rutin oleh CV Madu Apiari yang terdiri dari delapan program, yaitu 1) menghitung jumlah persediaan madu di perusahaan; 2) memaksimalkan pemanfaatan sosial media untuk menjangkau target konsumen kalangan muda; 3) melakukan perluasan wilayah pemasaran dengan membuat pemetaan pemasaran dan saluran distribusi setiap minggunya; 4) kerjasama yang sudah dan yang akan dijalin dengan pihak disributor baru, retailer, convinience store (Alfamart) dan eksportir; 5) membuat kontrak kerja (MoU) dengan mitra untuk mendapatkan jaminan keberlangsungan kerjasama yang telah dijalin; 6) aktif dalam mengikuti acara-acara pameran produk herbal alami disetiap daerah; 7) menyusun rencana kerja secara jelas dan tertulis serta melakukan evaluasi disetiap akhir pelaksanaan; 8) memperbaiki administrasi keuangan.

Rekomendasi program yang dilakukan secara rutin dan bertahap sebaiknya dikomunikasikan dengan para karyawan perusahaan. Menurut Russel (2013) berpendapat tentang pentingnya mengkomunikasikan strategi ke seluruh karyawan perusahaan sehingga mereka seharusnya terlibat dan berkontribusi terhadap pelaksanaan strategi untuk dapat merealisasikan strategi kedalam praktek bisnis yang menghasilkan kesuksesan kinerja bagi perusahaan.

Gambaran rancangan arsitektur strategi pertahunnya pada tahun 2018-2019, aktivitas yang akan dilaksanakan yaitu dalam hal pemasaran diluar wilayah Jabodetabek dan beberapa Pemasaran terbesar CV Madu Apiari Mutiara berada di wilayah Jabodetabek terutama daerah Depok dan Bogor. Di tahun 2018-2019 ini perusahaan ingin melakukan pengembangan pasar dengan membuka beberapa outlet/stand penjualan sendiri dikota-kota besar seperti Jakarta, Bandung, Semarang dan Surabaya. Hal ini dibentuk agar perusahaan dapat bersaing dengan industri madu lainnya terutama di wilayah Jawa Tengah dan Jawa Timur. Rancangan arsitektur strategi dapat dilihat pada Gambar 4.

Tahun 2019-2020 perusahaan harus membuat pemetaan pasar didaerah Jabodetabek dan luar Jabodetabek. Pemetaan pasar tersebut dilakukan untuk mengetahui wilayah mana saja yang sudah dilakukan pemasaran produk dan wilayah yang belum dilakukan pemasaran, untuk membuat pemetaan pasar tersebut harus ada rapat internal antara pemilik perusahaan dengan bagian pemasaran yang dapat dilakukan setiap minggunya untuk mengetahui perkembangan pasar dan konsumen saat ini. 
Tahun 2020-2021, CV Madu Apiari Mutiara bermaksud untuk melakukan pengembangan produk yaitu pengembangan dalam hal kemasan dan pengembangan varian produk. Pengembangan kemasan yang dilakukan perusahaan yaitu dengan memunculkan positioning pada label produk dan bentuk kemasan botol yang unik sehingga produk madu mudah diketahui oleh konsumen. CV Madu Apiari Mutiara juga mengembangkan inovasi produk turunan madu khususnya pada produk-produk kecantikan dan kesehatan. Label kemasan yang dibuat harus memiliki warna yang menarik dan lebih kontras, selain itu bentuk botol pada madu harus seragam hanya saja volumenya yang berbeda-beda hal ini dapat menjadi ciri khas madu botol perusahaan (Rosalina, 2012).

Sasaran perusahaan pada tahun 2022 CV Madu Apiari Mutiara menjadi perusahaan yang berkompeten dalam bidang madu yang pada akhirnya perusahaan ini dapat dikatakan sebagai Rumah madu hal ini dikarenakan banyaknya produk yang dihasilkan oleh CV Madu Apiari Mutiara. Semua produk yang dihasilkan tersebut bergerak dalam bidang kesehatan, kecantikan dan minuman yang sebagian besar merupakan kebutuhan konsumen pada umumnya. Ketersediaan bahan baku juga harus selalu terpenuhi degan baik agar dapat memenuhi permintaan produk dari konsumen.

\section{Implikasi Manajerial}

Faktor internal dan eksternal perusahaan sangat berpengaruh kuat terhadap perusahaan CV Madu Apiari Mutiara. Dengan kekuatan, kelemahan, peluang dan ancaman yang terdapat di CV Madu Apiari Mutiara, manajemen perusahaan harus memanfaatkan strategi SO yang merupakan prioritas strategi yang paling utama dalam alternatif strategi. Strategi SO, yaitu memperluas wilayah pemasaran dan meningkatkan inovasi produk kecantikan dan kesehatan.

\section{KESIMPULAN DAN SARAN}

\section{Kesimpulan}

Faktor-faktor internal dan eksternal yang berpengaruh terhadap pengembangan dan persaingan usaha madu pada CV Madu Apiari Mutiara, yaitu faktor-faktor internal terdiri dari kekuatan dan kelemahan adapun kekuatan yang dimiliki CV madu Apiari Mutiara, yaitu kualitas produk, karyawan yang kompeten, produk yang beragam, SOP pada divisi produksi, penelitan dan pengembangan. Kelemahan yang dimiliki perusahaan yaitu keterbatasan bahan baku madu, kurangnya fasilitas produksi, pemasaran produk pasif, dan produk madu yang mudah ditiru oleh pesaing mulai dari bentuk kemasan dan warna madu. Faktor-faktor eksternal yang memengaruhi pengembangan dan persaingan usaha madu pada CV Madu Apiari Mutiara terdiri dari peluang dan ancaman. Peluang CV Madu Apiari Mutiara terdiri dari pelanggan loyal, lokasi pemasaran yang masih luas, permintaan madu yang meningkat karena pola hidup sehat, teknologi informasi, inovasi produk kecantikan dan kesehatan. Ancaman perusahaan terdiri dari kenaikan harga bahan baku, kelangkaan bahan baku, persaingan antar perusahaan sejenis, dan pesaing menciptakan citra produk dengan baik.

Prioritas strategi yang diterapkan pada CV Madu Apiari Mutiara dalam mengusahakan madu mulai dari prioritas pertama hingga keenam adalah memperluas wilayah pemasaran, meningkatkan inovasi produk kecantikan dan kesehatan, membuat pemetaan saluran distribusi dan pemasaran, mempertahankan kualitas produk dan kredibilitas perusahaan, memunculkan keunikan produk, menambah jumlah koloni lebah untuk beternak sendiri dan peningkatan modal perusahaan.

Rekomendasi program yang diturunkan dari alternatif strategi dalam pengembangan strategi bersaing CV Madu Apiari Mutiara yaitu berjumlah dua belas program yang harus dijalankan secara bertahap dan terdapat delapan program yang harus dijalankan secara rutin.

\section{Saran}

Saran yang dapat diberikan kepada CV Madu Apiari Mutiara yaitu selalu menjaga ketersediaan bahan baku, kualitas dan kebersihan madu agar konsumen selalu loyal terhadap produk CV Madu Apiari Mutiara, rapat antara pemilik perusahaan dan karyawan sebaiknya dilakukan minimal satu bulan sekali untuk mengetahui perkembangan setiap divisi dan melakukan perencanaan kegiatan yang akan dilakukan setiap harinya. Diharapkan pengimplementasian alternatif strategi bersaing usaha madu pada CV Madu Apiari Mutiara dilakukan dengan kerjasama yang baik dan komitmen yang tinggi dari seluruh karyawan yang ada diperusahaan dan untuk penelitian selanjutnya 
perlu dilakukan analisis pemasaran dan perkembangan penjualan produk inovasi baru di CV Madu Apiari Mutiara untuk meningkatkan penjualan dan pemasaran perusahaan.

\section{DAFTAR PUSTAKA}

Banuelas R, Antony J. 2004. Modified analytic hierarchy process to incorporate uncertainty and managerial aspect. International Journal of Production Research (42)18: 3851-3872.

Dalalah D, Al-Oqla F, Hayajneh M. 2010. Application of the analytic hierarchy process (AHP) in multi-criteria analysis of the selection of cranes. Jordan Journal of Mechanical and Industrial Engineering (JJMIE) (4)5: 567-578.

Darmawan H, Daryanto A, Sukardi. 2015. Strategi pengembangan PT XYZ dalam agribisnis teh hijau. Jurnal Manajemen 19(1): 85-100. https:// doi.org/10.24912/jm.v19i1.107.

David FR. 2009. Manajemen Strategis: Konsep. Edisi 12. (Terjemahan). Jakarta. Penerbit Salemba Empat.

David ME, David FR, David FR. 2016. The quantitative strategic planning matrix: a new marketing tool. Journal of Strategic Marketing 25(4): 342-352. https://doi.org/10.1080/0965254X.2016.114876 3.

Dugo THN. 2011. Arsitektur strategi PT Petrokimia Gresik 2010-2020. [Tesis]. Bogor: Institut Pertanian Bogor.

Ghorbanian MR, Amini J, Saboorifard M. 2015. Evaluating and prioritizing the aspects of SWOT matrix using the statistical methods and the analytical hierarchy process (AHP) (case study: Iranian oil pipeline and telecommunication company, northwest region). Journal of Scientific Research and Development 2(6): 270-260.

Kamila R. 2017. Analisis pengembangan bisnis madu pada CV Ath-Thoifah dengan pendekatan business model canvas. Jurnal Agribisnis Indonesia 5(2): 174-175.

Oktavia E, Marimin, Djohar S. 2017. Strategic architecture in poultry company. Jurnal Dinamika Manajemen 8(2): 245-258. https:// doi.org/10.15294/jdm.v8i2.12764.

O'Regan NS, Martin A, Gallear D. 2008. Leaders, Loungers. Laggards. The strategic planning environment performance relationship revisited in manufacturing SME. Journal of Manufacturing Technology Managemenent 19(1): 6-21. https:// doi.org/10.1108/17410380810843426.

Oreski D. 2012. Strategy development by using SWOTAHP. TEM Journal 1(4): 285-286.

Osuna EE. 2007. Combining SWOT dan AHP techniques for strategic planning. ISAHP 2007. 2007 Agus 2-6; Vina Del Mar, Chili. Vina Del Mar: ISAHP: 1-8.

Rosalina Y. 2012. Desain kemasan untuk meningkatkan nilai tambah madu bunga kopi sebagai produk unggulan daerah. Jurnal Agroindustri 2(1): 1213.

Russel RH. 2013. How smart leaders translate strategy into execution. Journal of Harvard Business Review 1(3): 11-12.

Saaty TL. 2008. Decision making with the analytic hierarchy process. International Journal. Services (1)1: 83-98.

Setiawan A. 2016. Strategi pengembangan usaha lebah madu kelompok tani setia jaya di desa rambah jaya kecamatan bangun purba kabupaten rokan hulu. Jurnal Online Mahasiswa Faperta 3(1): 8-9.

Solihin I. 2012. Manajemen Strategik. Jakarta: Erlangga.

Suherman D. 2017. Strategi pemasaran madu berdasarkan karakteristik konsumen di kota bengkulu. Jurnal Sains Peternakan Indonesia 12(2): 172-173. https://doi.org/10.31186/jspi. id.12.2.171-183.

Tan J, Tan D. 2005. Environment strategy co-evolution and co-alingment: a staged model of chinese SOE's under trasnsisition. Strategic Management Journal (2)26: 141-157. https://doi.org/10.1002/ smj.437.

Top Brand Award. 2016. Top Brand Index 2016 Fase 2. http//www.topbrand-award.com/top-brandsurvey/surveyresult/top_brand_index_2016 fase_2 [2017 nov 28].

Triantaphyllou E, Mann SM. 1995. Using the analytic hierarchy process for decision making in engineering applications: some challenges. Journal of Industrial Engineering: Applications and Practice 1(2): 35-44.

Yoshida DT. 2006. Arsitektur Strategik: Sebuah Solusi Meraih Kemenangan Dalam Dunia Yang Senantiasa Berubah. Jakarta: Elex Media Komputindo. 
Wulandari K. 2017. Strategi pengembangan unit usaha bioetanol pada PT Perkebunan Nusantara XI dengan pendekatan A'WOT. Journal of Agribusiness and Rural Development Research 3(2): 76-77.
Zarei M, Paghaleh MJ. 2011. Strategic management of business in food industry: by an integrated deployment of AHP and freeman model. Business Management Dynamics 1(3): 47-52. 